\title{
Challenges of sustainable rural tourism development in KwaZulu-Natal
}

\author{
Thandi A. Nzama ${ }^{6}$ \\ Department of Recreation and Tourism \\ atnzama@pan.uzulu.ac.za
}

\begin{abstract}
Tourism has emerged as one of the strategic instruments and policy tools for community and regional development in Southern Africa (Rogerson, 2007 in Saarinen, et al. 2009). Gradually, tourism is rotating to the political centre stage as an instrument of social and economic empowerment (Binns \& Nel, 2002). Consequently, local government authorities have instituted initiatives for promoting tourism as a sustainable economic driver in their municipalities. Sustainable rural tourism development is widely supported because it does not threaten the integrity of the ecological and social systems upon which communities and societies are dependent. Marien \& Pizam in Wahab \& Pigram (2004: 165) argue that since communities are constantly changing, like the nature of tourism, evaluating community's sensitivity and associated impacts should not be regarded as an temporary event but as an ongoing process.

This study focuses on the strategic development of sustainable rural tourism in the rural areas of KwaZulu-Natal, more specifically Ntambanana Municipality. The objectives of the study were as follows: (a) To identify natural and sociocultural resources that can be used for rural tourism development. (b) To assess the participation level of local communities in tourism development. (c) To establish the extent to which the tourism policies and strategies are implemented. (d) To identify the capacity of the local communities to develop tourism products. (e) To reveal the challenges that impede sustainable rural tourism development. Data from a sample size of 320 were collected and analysed using the SPSS programme.

The findings of the study indicated that there is potential for natural, cultural and heritage tourism due to the existence of a variety of related resources. The findings, however, indicated that local people are not aware of these resources hence the lack of participation in tourism development. Various strategies were suggested for raising social awareness and the promotion of cultural and heritage resources in the rural area.
\end{abstract}

Keywords: Tourism, rural tourism, sustainable tourism development, socio-cultural resources.

\section{Introduction}

This paper presents the findings of research conducted in various rural areas in KwaZulu-Natal that are currently involved in various activities aimed at motivating local communities to participate in sustainable rural tourism development activities. The focus in this paper is on Ntambanana Municipality which serves as the case study. The Ntambanana authorities wanted to promote sustainable rural tourism development with the aim of improving the quality of life of the local residents. In doing so, it hoped to get local communities involved in the planning and development of tourism in their area. The efforts of the authorities are underpinned by the understanding that the success of tourism development depends on the extent of involvement of local communities in the tourism planning and development processes (Page \& Dowling, 2002; Wahab \& Pigram 2004). Tourism, and more specifically rural tourism, has been seen as a vehicle that has the potential to influence socio-economic changes through the use of natural and socio-cultural economic resources. It is this use, particularly the consumption pattern of socio-cultural resources, that has highlighted the significance of sustainability in rural tourism development, which has also turned tourism into not only an economic but also a social and political agent that affects wider natural and socio-cultural environments in various ways (Page \& Dowling, 2002; Wahab \& Pigram, 2004).

Most rural areas in South Africa are characterised by a lack of infrastructure, high illiteracy rates, unemployment, underdevelopment, poverty and a general lack of knowledge and understanding of tourism development issues. Several studies have recommended various approaches, such as the pro-poor strategies [PPT Strategies] that can be used to improve the living conditions and increase tourism development benefits for rural poor people from tourism development (Ashley \& Roe, 2002:6I). A number of these pro-poor strategies [PPT] strategies have been tried and implemented with varying degrees of success in some rural areas, but they have not yet been implemented in this particular study area. There are many reasons for the discrepancy in the success rate of the implementation of these strategies. Some of these include the heterogeneity of socio-political landscapes within each area; social cohesiveness and social mix, which should be conducive to rural tourism development as well as vast differences between the needs of the tourism industry and tourists, on the one hand, and those of the local inhabitants of rural areas on the other hand. Communities living in abject poverty worry more about the satisfaction of their basic needs and less about satisfying the needs of the tourists, which is the main focus of the tourism industry.

6. Dr. Thandi Nzama is a Senior Lecturer and Head of the Department of Recreation and Tourism at the University of Zululand, South Africa. 
This paper presents the findings of the research conducted in various rural areas that are currently involved in various activities aimed at motivating local communities to participate in sustainable rural tourism development activities. Their efforts are underpinned by the understanding that the success of tourism development depends on the extent of involvement of local communities in the tourism planning and development processes (Page \& Dowling, 2002; Wahab \& Pigram, 2004).

\section{Aim and objectives of the study}

The broad aim of this study is to establish the challenges that impede sustainable rural tourism development as well as to find ways in which the utilisation of the socio-cultural resources is managed economically, socially, culturally and environmentally in order to ensure sustainable tourism development in these areas. This main aim of this study was then narrowed down to the following objectives.

(a) To identify natural and socio-cultural resources that can be used for rural tourism development.

(b) To assess the participation level of local communities in tourism development.

(c) To establish the extent to which the tourism policies and strategies are implemented.

(d) To identify the capacity of the local communities to develop tourism products.

(e) To reveal the challenges that impede sustainable rural tourism development.

\section{The theoretical framework}

Ntambanana Local Municipality [NLM] is mainly a rural area located within the Uthungulu District Municipality on the north coast of KwaZulu-Natal. This local municipal area is rich in cultural and heritage resources which have not been used to the benefit of the local community. Ntambanana Municipality, like many other predominantly rural municipalities, is currently seeking to attract tourists to its area using these local resources, specifically the cultural, heritage and natural assets, in order to improve the quality of life of the residents. Tourism has been linked with poverty reduction for a number of reasons, such as its ability to thrive in rural areas using readily available natural and socio-cultural resources thus creating job opportunities for the local residents (Ashley \& Roe, 2002). There are several approaches, sometimes referred to as PPT strategies, such as community-based tourism, responsible and/or sustainable tourism as well as ecotourism initiatives that have been recommended to make tourism a real tool for poverty reduction in rural areas (Ashley \& Roe, 2002). These strategies were first suggested several years ago but this study found that there are still serious challenges that make sustainable rural tourism development remain a dream rather than a reality in rural areas.

The World Tourism Organisation defines sustainable tourism development as "meeting the needs of present tourists and host regions while protecting and enhancing opportunity for the future tourists to meet their own needs. It is envisaged as leading to management of all resources in such a way that economic, social, and aesthetic needs can be fulfilled while maintaining cultural integrity, essential ecological processes, biological diversity, and life support systems" (WTO in Cooper et al., 2008: 216). In addition to the management of resources, sustainable tourism development also refers to the optimal use of natural and cultural resources for national development on an equitable and self sustaining basis to provide a unique visitor experience and an improved quality of life through partnership among government, the private sector and communities (Cooper et al., 2008: 216).

To ensure that development and promotion of rural tourism using locally available resources is sustainable, local community participation is inevitable (Wahab \& Pigram, 2004). Currently there is no consensus on the precise definition of what rural tourism is; however, Viljoen and Tlabela (2007:I) point out that "rural tourism consists of leisure activities carried out in rural areas, and includes different types of tourism activities such as community-based tourism, ecotourism, cultural tourism, adventure tourism, guest tourism, back packing, riding and agritourism". Local people are custodians of the resources in their areas such as socio-cultural and heritage resources and, therefore, should be actively involved in the identification of the assets that will be used in any form of rural tourism development.

Fairer-Wessels (2009:101) in Saarinen et al. (1990), points out that in recent years a vast amount of changes has been observed in both production and consumption of heritage tourism-related products. Heritage attractions have developed a niche in the tourism industry and are now regarded as part of contemporary consumption (Apostolakis, 2003:796). It is imperative that the production and consumption of these resources is done in a sustainable manner. There are three key components that are necessary in ensuring sustainable rural tourism development. These are the infrastructural (roads, electricity, etc.), material (natural resources, public and private structures, etc.); as well as the immaterial components (the capacity of the local people to utilise the existing resources, political and socio-cultural environments, etc.). The existence of these components serves as the foundation for sustainable rural tourism development.

Inkanyiso, Jnl Hum \& Soc Sci 2010, 2(I) 
This type of development is envisaged as leading to management of all resources in such a way that economic, social, and aesthetic needs are fulfilled while maintaining cultural integrity, essential ecological processes as well as biological and life support systems. This assertion, therefore, means that if the utilisation of these resources is well managed economically, socially, culturally and environmentally, sustainable rural tourism development can be realised for the present and future generations of this area.

The South African government has become aware of the potential for tourism to play a meaningful role in contributing to the economic development of the country, particularly the rural areas. Tourism has been seen as a tool with a potential to enhance the development of rural areas on an ecologically and economically viable basis, and also as a vehicle that can improve the quality of life of people living in the rural areas. In endorsing this realisation, the government has prioritised tourism as one of the five economic growth sectors on which to focus its effort to support investment and facilitate growth (SAT 2008). There are, however, various challenges relating to spreading tourism to rural areas. In an attempt to address these challenges local governments have directed their efforts to encouraging the infiltration of tourism in these rural areas and consequently, there have been many initiatives to highlight tourism as an economic driver in its various forms. Cultural experiences and their diversification as well as tours to rural areas were identified as "product gaps" by the Global Competitive Project (SAT, 2004: 2).

South Africa's rich and varied cultural and natural resources have given the country a competitive advantage and a basis for tourism development and growth (Van Vuuren, 2004; Viljoen \& Tlabela, 2007). The White Paper on the Development and Promotion of Tourism in South Africa has contended that the prime tourism attractions are not located in the city centres but in the rural areas (DEAT, 1996). It is important to develop tourism in rural areas like Ntambanana Municipality in order to increase the participation of the rural poor in the development of tourism, thus distributing the potential benefits more evenly across the province (Holland, Burian \& Dixey (2003) in Viljoen \& Tlabela (2006:I); Visser, 2004). It is imperative that resources for tourism development are used in a sustainable manner which dictates that tourism should be planned, developed and operated within the context of sustainable development principles. Tourism development in rural areas is a challenge that needs to be managed. Ashley \& Roe (2002) warn that in order to sustain participation by local communities, expectations should be managed. They should be aware that results will be slow and it then becomes important to develop short-term benefits and to build local ownership.

To ensure the sustainable use the local resources for rural tourism development, there are two critical preconditions that need to be taken into consideration (I) participation of the local communities and (2) a strategic development plan (Viljoen, Ringdahl, Adams \& Tlabela, 2004; Wahab \& Pigram, 2004). A tourism policy is an indispensable precursor for any tourism planning and development as it provides a framework for tourism development strategic planning. A tourism policy draws developmental parameters from the availability of resources, the nature of the tourism products, marketing, envisaged target markets, outlined alternatives, choices, strategies and plans. Generally, the tourism policy should specify the tourism goals which would include economic goals, socio-cultural goals, environmental goals, market development goals and government operations (political) goals. Once the tourism policy has been established, a tourism strategy is needed to achieve the goals and objectives of the policy. It is, therefore, clear that in order for Ntambanana Municipality to engage in any form of rural tourism development it needs a clear policy and a strategic plan. It is important for local people to understand that the successful implementation of the strategy requires action at various levels on "several fronts including product development, marketing, planning, policy and investment” (Ashley \& Roe, 2002:80).

Due to the perceived abundance of cultural and heritage resources in rural areas, the Ntambanana Municipality has seen cultural and heritage tourism as a form of tourism that can contribute to local economic development. Cultural tourism is a branch of tourism aimed at investigating ways in which culture can be used to create value in the tourism sector. It is also seen as a way marginalised communities and individuals can benefit from tourism on the basis of their cultural resources (Viljoen, 2007). The extent of benefits is determined by the extent to which local communities are able to leverage cultural knowledge and skills as resources for entrepreneurship (Van Vuuren, 2004). This means that local people should be able to turn cultural and heritage resources into marketable products of profitable value. In most cases local communities' lack knowledge of the scale, volume and economic significance of cultural tourism, and this results in a lack of enthusiasm in participating in tourism development issues, thus translating to less than expected benefits for local communities (Page \& Thorn, 1998 in Hall \& Lew, 1998).

Cultural tourism relates to visits by persons from outside the host community, motivated wholly or in part by interest in historical, artistic, scientific, lifestyle or heritage offerings of a region, community or group (Magnussen \& Visser, 2003). Seen from this perspective, cultural tourism creates opportunities for cultural aspects which are of interest to the visitor to be marketed as such which may include the customs and traditions of people, their heritage, history and their ways of life (DEAT, 1996). Cultural tourism has been found to provide interesting opportunities for tourists with special interests 
(Ivanovic, 2008). Special interest tourism would create an opportunity for the municipality to provide customised leisure and recreation experiences based on individually or group expressed interests and needs.

According to Smith (2003) cited in Ivanovic, (2008) cultural tourism comprises the following categories:

- Heritage tourism

- Arts tourism

- Urban cultural tourism

- Rural cultural tourism

- Indigenous cultural tourism

- Contemporary cultural tourism.

With the exception of urban tourism, the Ntambanana Municipality has the potential to initiate all these forms of cultural tourism as part of its sustainable rural tourism development drive.

Heritage is a broad concept that includes the natural as well as cultural environment, biodiversity, collections, past and continuing cultural practices, knowledge and living experiences. Fairer-Wessels (2009:10I) in Saarinen et al. (2009) defines heritage as the legacy that is passed on to future generations and further describes it as history which has been processed through mythology, ideology, nationalism, local pride, romantic ideas or marketing into a commodity. Heritage encompasses the long processes of historical development which forms an essence of diverse national, regional, indigenous and local identities. Heritage is, therefore, irreplaceable and it provides a dynamic reference point for growth and change, in which case heritage is basically the present day use of the past (Ashworth, 1994; Timothy \& Boyd, 2006). A particular heritage provides a unique collective memory of each locality or rural community and is largely concerned with the interpretation and representation of the past.

Heritage tourism is one of the oldest forms of travel that is a subset of cultural tourism which is based on heritage. Heritage is, in this case, the core of the product that is offered and is the primary motivating factor for travelling (Timothy \& Boyd, 2006; Magnussen \& Visser, 2003). In most cases, heritage tourism has become a key driver of cultural tourism which has at its core the present consumption of the past, utilising both tangible and intangible features of the landscape (Timothy \& Boyd, 2006). With its rich heritage, Ntambanana can embark on heritage tourism as a component of its rural tourism development project.

Culture, heritage and the arts have proved to have the potential of attracting tourists in many parts of the world. This can be done through showcasing the values, life styles and traditions of indigenous cultural communities by staging activities such as festivals, fairs, rituals, etc. The other form of tourism that would thrive in the Ntambanana Municipality is creative tourism. Creative tourism is the type of tourism that allows tourists to develop their creative skills through active participation in workshops and other learning experiences which are characteristic of the local community (Ivanovic, 2008). The challenge is turning all these ideas into rural tourism products, which requires skills in packaging and aggressive marketing.

In the process of planning and developing cultural and heritage tourism products, selecting the most interesting sites and assigning particular presentation and interpretation is crucial. Making history and cultural heritage accessible, transparent and attractive requires careful consideration of the nature of a product. According to Smith (2003) in order to create a successful and attractive cultural package or product for tourism consumption, it is important to understand the cultural attraction mix strategies which include the following:

- Bunching/clustering of cultural attractions - clustering of several weak attractions into a strong primary attraction with greater historical significance

- Theming of cultural attractions - an attraction is themed in order to enhance its uniqueness.

- Labelling of cultural attractions - emphasis is placed on the functional use of the attraction.

- Altering of cultural attractions - applied to potential tourist attractions only.

Packaging of products also involves the presentation and interpretation of cultural and heritage products. Presentation includes selection, evaluation, preservation and conservation of important heritage objects in museums and other heritage sites. This is done by facilitating public access to facilities, as well as encouraging participation, which would enhance public appreciation of the heritage. Interpretation is necessary in order to communicate the meaning and value of the cultural heritage object and also to stimulate, facilitate and extend people's understanding. It is believed that through their understanding of a place people would be more concerned about the development and conservation of cultural and heritage landscapes. There are a number of challenges that have been associated with tourism development in rural areas, such as a general lack of capacity and tourism development related skills. What cripples the impetus for

Inkanyiso, Jnl Hum \& Soc Sci 2010, 2(I) 
development is the lack of business management skills and general understanding of tourism and the tourism industry (Ashley \& Roe, 2002).

\section{Methodology}

A combination of qualitative and quantitative approaches was used to address the research questions. To ensure the best results, respondents were selected from four out of eight wards that make up Ntambanana Municipality. Random sampling was used to get the total sample size of 72 respondents from the four wards. The sample included respondents from four population sectors or stakeholders: (a) tourism service providers; (b) Government officials working in the tourism unit of the Municipality; (c) the youth, mainly high school learners older than 16 years; and (d) the residents of Ntambanana Municipality.

Questionnaires were used to collect quantitative data, and for qualitative data, observation method, focus groups, documentary analysis techniques, visitor-entry book as well as group and individual interviews were used. The sources of secondary data related to this study included policy documents, municipal IDPs, as well as the work done by such National and Provincial Government departments. Quantitative analysis of data collected through the questionnaires was done using the statistical package called Statistical Package for Social Sciences (SPSS).

\section{Findings of the study}

The findings were guided by the objectives of the study which cover the following areas of analysis: resources used for rural tourism development; community participation in tourism development; implementation of tourism policies; community's development of tourism products; and challenges that impede sustainable rural tourism development. The findings are discussed below.

\subsection{Natural and socio-cultural resources available in the area}

The first objective of the study was to identify natural and socio-cultural resources that can be used for rural tourism development. Based on the environmental scan, the findings indicated that the Ntambanana Municipality, like many rural localities, is well endowed with natural as well as socio-cultural resources that can be developed into tourism products. The abundance of natural, cultural and heritage resources indicate that there are opportunities for natural as well as cultural and heritage tourism development in the Ntambanana Municipality. Table I provides a list of resources that were perceived to have a potential for rural tourism development.

Table I Available resources found in Ntambanana

\begin{tabular}{|c|c|c|c|c|}
\hline Rank & Natural \& socio-cultural resources & $\begin{array}{l}\text { Absolute } \\
\text { Frequency }\end{array}$ & $\begin{array}{c}\text { Frequency } \\
\%\end{array}$ & $\begin{array}{l}\text { Type of rural tourism } \\
\text { that can be developed }\end{array}$ \\
\hline 01 & Natural landscape with traditional homesteads & 59 & $82 \%$ & Cultural heritage tourism \\
\hline 02 & Indigenous forests & 48 & $67 \%$ & Nature based tourism \\
\hline 03 & Wildlife & 45 & $63 \%$ & Wildlife appreciation; ecotourism, \\
\hline 04 & Rivers and dams & 43 & $60 \%$ & Nature based tourism \\
\hline 05 & Farms & 39 & $54 \%$ & Agri-tourism \\
\hline 06 & Reed & 37 & $51 \%$ & Cultural heritage \\
\hline 07 & Cultural village & 32 & $44 \%$ & Cultural \\
\hline 08 & Senior citizens (oral history) & 30 & $42 \%$ & Cultural heritage tourism \\
\hline 09 & Open land suitable for camping facilities & 29 & $40 \%$ & Nature based tourism \\
\hline 10 & Various bird species & 28 & $39 \%$ & Bird appreciation \\
\hline $\mathrm{II}$ & Various historical sites & 25 & $35 \%$ & Cultural Heritage tourism \\
\hline
\end{tabular}

$[n=72$. Some of the subjects gave more than one response for available resources]

The Ntambanana Municipality has a rich history that can be packaged and presented for the enjoyment of tourists as part of heritage tourism in local museums, cultural villages, information centres, community halls, etc. With its farms and agricultural environment Ntambanana Municipality has the potential for developing and promoting tourism activities such as agricultural product tasting, farm related activities, agricultural fairs and festivals. These are opportunities for tourism 
development that have not been explored. In other words, it is necessary to emphasise the relationship between agriculture and tourism, considering that farming is a strategic factor in the economic development of an area.

\subsection{Participation level of local communities in tourism development}

The second objective was about assessing the participation level of local communities in tourism development. Respondents were asked if adequate opportunities have been created for them to participate in any rural tourism activity or if they had attended any meeting that discussed tourism opportunities in the area. As depicted in Figure I, the majority of the respondents (54\%) indicated that there had been inadequate opportunities created hence they had not been involved in any way and only $15 \%$ of the respondents indicated that they were currently involved in tourism activities such as product development. A significant number (31\%) of the respondents were not sure but were willing to participate if invited to do so. The lack of enthusiasm and poor participation in tourism development initiatives could result from the high illiteracy rate and the lack of understanding of the economic benefits of tourism.

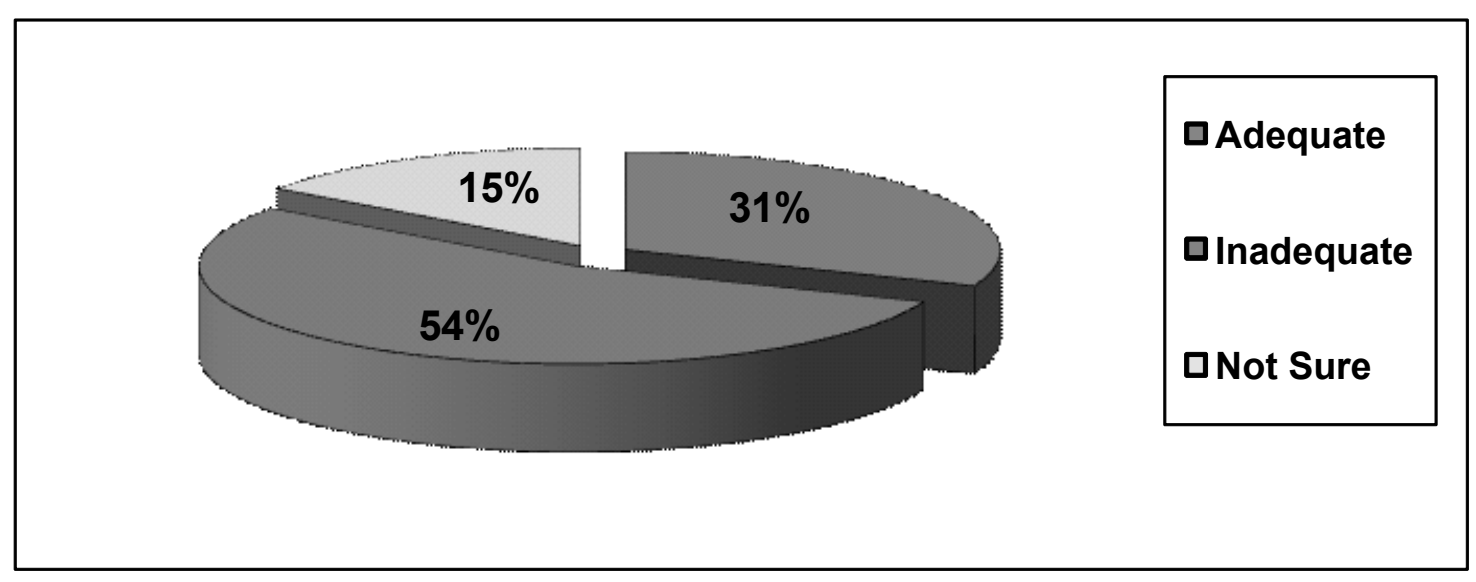

Figure 1 Participation in tourism development

It was not surprising that when the respondents were asked if they thought the existing resources were adequate to stimulate tourism development in their area, the majority of them (52\%) who were mainly community members indicated that the resources were inadequate, while $53 \%$, who were the officials, indicated these were adequate and $44 \%$ of the respondents, mainly the service providers, were not sure of the adequacy of the resources. The findings indicated that the officials of the Ntambanana Municipality, who are supposed to lead tourism development, are positive about the adequacy of the resources that are readily available to stimulate tourism development in the area. Due to their lack of participation, local community members are not aware of whether the existing resources can serve as a basis for stimulating tourism development. These responses can be attributed to the fact that local community members have little knowledge of the tourism potential of the resources in their area.

Table 2 Perceived adequacy of existing natural resources

\begin{tabular}{|l|l|l|l|}
\hline Response & Community Members & Service Providers & Officials \\
\hline $\begin{array}{l}\text { Adequate } \\
\text { [Positive] }\end{array}$ & $19 \%$ & $28 \%$ & $53 \%$ \\
\hline $\begin{array}{l}\text { Inadequate } \\
\text { [Negative] }\end{array}$ & $52 \%$ & $28 \%$ & $20 \%$ \\
\hline $\begin{array}{l}\text { Not Sure } \\
\text { [Undecided] }\end{array}$ & $29 \%$ & $44 \%$ & $27 \%$ \\
\hline TOTAL & $100 \%$ & $100 \%$ & $100 \%$ \\
\hline
\end{tabular}

[ $n=72$. Some of the subjects gave more than one response for each variable]

The Ntambanana Municipality has a rich history that can be packaged and presented for the enjoyment of tourists in local museums, cultural villages, information centres, community halls, etc, which would be packaged as part of heritage tourism. With its rural environment, Ntambanana Municipality has potential for developing tourism activities such as farm tourism, agricultural tourism, fairs, festivals, etc. The responses could be the result of the local people's lack of Inkanyiso, Jnl Hum \& Soc Sci 2010, 2(I) 
understanding of the relationship between agriculture and tourism as strategic factors in the economic development of their area.

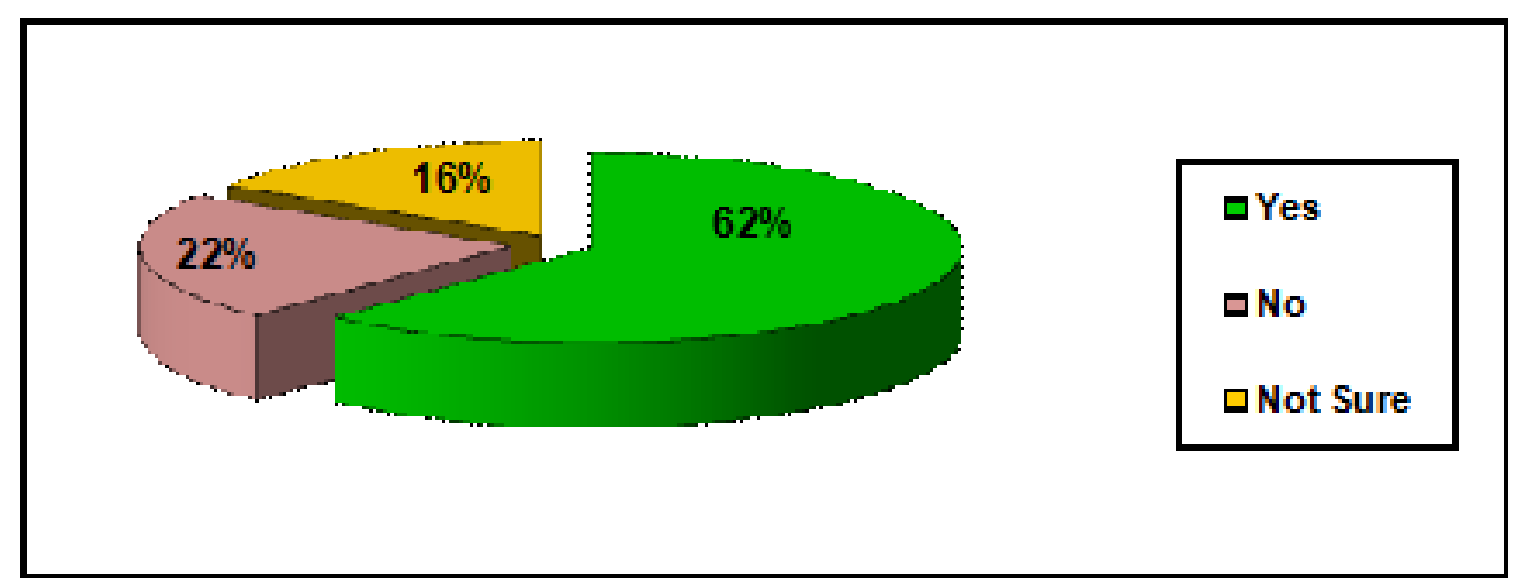

Figure 2 Perceived importance of tourism development

In order to consolidate the notion of the importance of tourism development in the Ntambanana Municipal area, the respondents were asked to give reasons for their support of tourism development and promotion. The reasons that were provided are listed in order of importance in Figure 3. The majority of respondents (68 percent) thought the "improved economy" and "job creation" (60 percent) were the most important reasons for promoting tourism development in the Ntambanana Municipality Area.

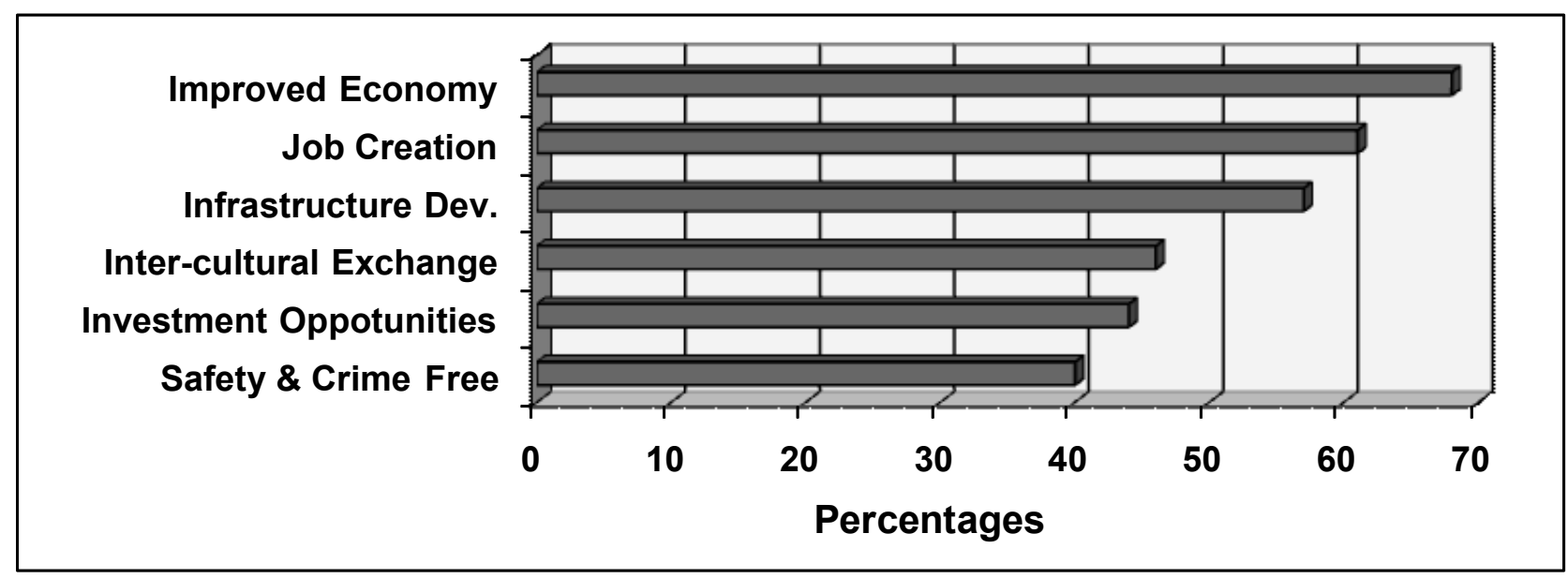

$[n=72$. Some of the subjects gave more than one response for each variable $]$

Figure 3 Reasons for the importance of tourism development

Furthermore, reasons such as infrastructural development (57\%) were seen as pointing to the need for improving the physical and spatial development of the Ntambanana Local Municipality. These findings are in line with the theory that indicates that rural tourism development has challenges ranging from logistical issues such as infrastructure to the availability of skills (Viljoen \& Tlabela 2006). The findings further indicate that inter-cultural exchange, investment opportunities, and the creation of a safe and crime free environment were also seen as important. The reason for these responses may be attributed to the shortage of jobs in the area.

5.3 The extent to which the tourism policies and strategies are implemented

The third objective was to establish the extent to which the tourism policies and strategies are implemented. As indicated earlier, a tourism policy is an indispensable precursor for any tourism planning and development as it provides a 
framework for tourism development strategic planning. A tourism policy draws developmental parameters from the availability of resources, the nature of the tourism products, marketing, envisaged target markets, outlined alternatives, choices, strategies and plans. Respondents were asked if they were aware of the tourism policy and strategy for their Municipality.

Table 3 Knowledge of existence of the tourism development strategy in the study area.

\begin{tabular}{|l|l|l|l|}
\hline Response & Existence Of Policy & Existence Of Strategy & $\begin{array}{l}\text { Need For New } \\
\text { Policy \& Strategy }\end{array}$ \\
\hline $\begin{array}{l}\text { Aware } \\
\text { [Positive] }\end{array}$ & $19 \%$ & $18 \%$ & $76 \%$ \\
\hline $\begin{array}{l}\text { Not Aware } \\
{[\text { Negative] }}\end{array}$ & $52 \%$ & $58 \%$ & $07 \%$ \\
\hline $\begin{array}{l}\text { Not Sure } \\
\text { [Undecided] }\end{array}$ & $29 \%$ & $24 \%$ & $17 \%$ \\
\hline TOTAL & $100 \%$ & $100 \%$ & $100 \%$ \\
\hline
\end{tabular}

$[n=72$. Some of the subjects gave more than one response for each variable]

A majority of the respondents indicated that they were not aware of the existence of tourism policies and strategies in the study area. A significant 29 percent of the respondents also indicated they were not sure of the existence of the tourism policy and the strategic plan. A majority (76 percent) of the respondents felt that there was a need for a new tourism policy and strategy for the Ntambanana Municipal area. The reason for this reaction from the respondents is the limited flow of information from the authorities who develop policies and the residents who are affected by these policies.

5.4 The capacity of the local communities to develop tourism products.

The fourth objectives was to identify the capacity of the local communities to develop tourism products. When asked if they knew how to package the natural and cultural resources into tourism products, the findings indicated that only $12 \%$ had an idea of what can be done to use the available resource for tourism development.

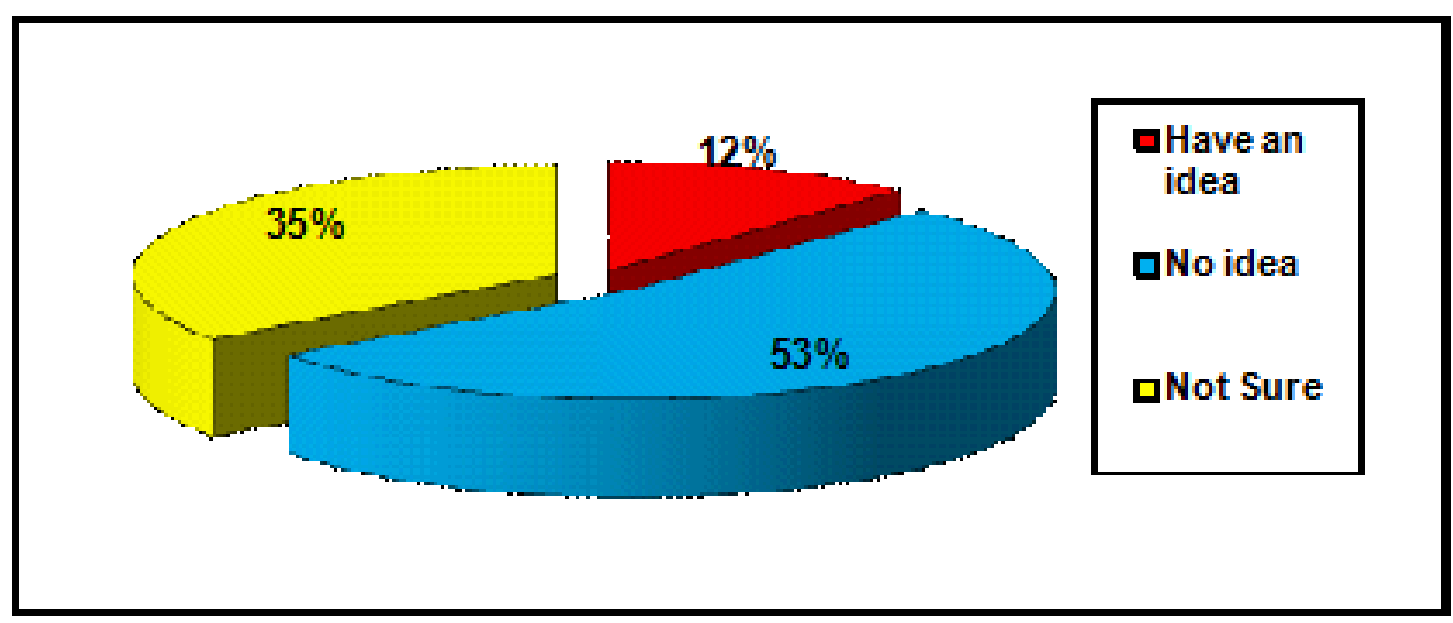

Figure 4 Knowledge of packaging existing resources into tourism products

The majority of the respondents (53\%) indicated that they had no knowledge of how to package the existing resources into tourism products. These responses clearly indicate that local community members lack the capacity and skills that are necessary for tourism development.

The respondents were asked to indicate whether they thought it is important to promote tourism development in their area. When asked if they were doing anything to improve their skills, the majority indicated that the government should provide resources for them to develop their area. 
5.5 The challenges of tourism development in the rural areas

There are many challenges that are related to tourism development in the rural areas which require action by various stakeholders at various levels. The findings of the research study revealed that major challenges include, but are not limited to the following factors:

\section{(a) Brain-drain of skills from rural areas}

Educated people tend to leave the rural areas soon after receiving their qualifications to seek better opportunities in urban areas. This brain drain leaves these rural areas with people who are unable to participate effectively in tourism development issues. Any intervention in this case has to start with capacity building which will enhance business related skills such as identifying business opportunities, initiating and running business enterprises, negotiation skills, etc. and increase their understanding of tourism and tourists' needs.

\section{(b) Dependency syndrome}

The respondents were asked who they thought was responsible for tourism development in their area; The majority indicated that they believed that the government was not only expected to take the leading role in tourism development but also to be responsible for the sustenance of their livelihood. They also seem to think that the government has to hold them by the hand and even tell them what to do. This community behaviour indicates a lack of confidence in themselves that they can be in control of tourism development of their area

\section{(c) The need for empowerment}

Members of the local community in the study area are still very reluctant to participate in rural tourism development activities and yet community participation has been seen as a key to sustainable tourism development. The findings of the study point to the need for developing both financial and non-financial empowerment strategies which are expected reduce the vulnerability of local people by increasing their independence and confidence in engaging in decision-making processes. This finding is supported by Becker (2006b), who asserts that it is necessary to negotiate for poverty alleviation opportunities that are likely to secure and improve the physical and emotional survival of the people.

\section{(d) Lack of basic infrastructure}

The lack of basic infrastructure such as roads disintegrates the link between rural areas and established tourist attractions thus leaving rural areas on the periphery of the tourism industry. Tourism cannot be developed in a vacuum, and therefore cannot afford to be detached from the mainstream of the tourism industry.

\section{(e) Lack of political will}

The government has the power to shape the rural tourism landscape in terms of how tourism is planned, promoted, managed and regulated. There are many influences which the government can harness that are outside the control of tourism itself and yet have a direct impact upon its development e.g. political rivalry which makes it difficult to initiate tourism projects in contested areas.

\section{(f) Lack of knowledge about resources transformation}

The challenges of rural tourism development are compounded by the lack of knowledge and skills to turn raw materials into marketable products. This process would produce spin-off in the form of job creation, employment and poverty alleviation in the rural area. Furthermore, this would lead to meeting the challenges of sustainable rural tourism development.

\section{(g) Inability to market the cultural products}

To ensure commercial viability of the rural tourism products it is imperative that attention be given to product quality, marketing and investment in business skills.

\section{(h) Inability to adapt to the pace of change}

Change in tourism is inevitable as tourists are becoming more knowledgeable and sophisticated, thus making new demands. It is therefore inconceivable that the world of tourism would change rapidly and rural tourism in the study area remain stagnant.

While the government is prepared to participate in tourism development, the problem has always been to find the correct mixture of market orientation and state intervention that can lead to more sustainable forms of tourism development. It is on the basis of this mixture that a set of arrangements can be devised between the government, the private sector and the local communities that would promote tourism development.

\section{Recommendations}

Based on the findings of this study it is clear that in order to create a successful and attractive cultural and heritage rural tourism package or product for tourism consumption, local communities need to have a broad understanding of the cultural attraction mix strategies. In addition to this understanding, local communities also need to acquire certain skills necessary to identify business opportunities, initiate and nurture those businesses. In order for sustainable tourism 
development in rural areas to thrive on a continual basis, it is, therefore, recommended that (a) the community members should work together in identifying the socio-cultural and heritage assets that can be packaged into tourism products; (b) the provision of capacity building programmes which would provide local communities with the basic skills be urgently introduced; (c) tourism road-shows be started in rural areas, so as to create awareness of the tourism benefits. (d) attention be given to the clustering of several weak attractions into a strong primary attraction with greater historical significance. (e) capacity building on packaging, presentation, interpretation and marketing of cultural and heritage rural tourism products as well as general business management, be provided to ensure sustainable rural tourism development.

\section{Conclusion}

This study pointed at a number of ways in which rural areas can be positioned as a 'must-visit' natural, cultural and heritage "rural" tourist destination taking into consideration the dynamic character of the tourism industry. The study has further highlighted the significance of active involvement by local communities who are the custodians of the resources that can be used for tourism development. The range of natural, cultural and heritage tourism products found in rural areas is very wide; therefore, it is important to select a procedure to be followed in the process of product planning and development. It is also necessary to link the resources available with the skills that are required by the local communities in order for them to participate effectively in sustainable rural tourism development.

\section{References}

Ashley, C. \& Roe, D. (2002). Making tourism work for the poor: Strategies and challenges in South Africa. Development Southern Africa. 19 (I): 6I-82.

Ashworth, G. Z. (1994). Cultural tourism and environmentally sustainable regional development. [Online] sadapt.inapg. inra.fr/ ersa 2007/papers/50.RTF. [accessed 23-06-2009]

Apostolakis, A. (2003). The convergence process in heritage tourism. Annals of Tourism Research 930 (4) 795-8/2.

Becker, F. (2006b). Institutional reform, urbanisation, politico-economic and socio-cultural transformation in Northern Namibia: A pro-poor investigation into poverty alleviation opportunities. Invited Poster. Volksvagen Foundation Workshop on Resources, Livelihood, Management Reforms and Processes of structural change. Gobabeb / Namibia, 18-23 September 2006.

Binns, T. \& Nel, E. (2002). Tourism as local development strategy in South Africa. The Geographical Journal I68 (3), 235 - 247.

Bohlman, P. (1988). Traditional Music and Cultural Identity: Persistent Paradigm in History of Ethnomusicology. In Yearbook for Traditional Music, Vol XX: (26-42).

Butler, R.W. \& Hinch, T. (Eds) (1996). Tourism and Indigenous People. London: International Thomson Business Press.

Cooper, C.; Fletcher, J.; Fyall, A.; Gilbert, D. \& Shepherd, R. (2008). Tourism: Principles and Practice. New York: Prentice Hall.

DEAT (1996). The White Paper on the Development and Promotion of Tourism in South Africa. Department of Environmental Affairs and Tourism. Pretoria.

Fairer-Wessels, F. A. (2009). Cultural Heritage Tourism and Sustainability in South Africa: The case of the Cradle of Humankind. In Saarinen, J, Becker, F., Manwa, H \& Wilson, D. (2009) Sustainable Tourism in Southern Africa: Local Communities and Natural Resources in Transition. Toronto: Channel View Publications.

Ivanovic, M. (2008). Cultural Tourism. Cape Town. Juta \& Company Ltd.

Magnussen, A. \& Visser, G. (2003). Developing a World Heritage Site: The Cradle of Humankind. Africa. Insight Vol 33 nol/2pg 78.

Miller, S. (1999). An Overview of the Sector. In Leask, A. \& Yeoman, I (Eds) (2000). Heritage Visitor Attraction: An Operations Management Perspective. New York: Cassel Publishers.

Page, S.J. \& Dowling, R. (2002). Ecotourism. Harlow: Prentice Hall.

Rogerson, C.M. (2007). Reviewing Africa in the global tourism economy. Development Southern Africa 24 (30, 361 - 380.)

Rogerson, C.M. \& Visser, G. (2004). Tourism Development Issues in Contemporary South Africa. Pretoria. Africa Institute of South Africa,

SAT [South African Tourism] (2004). Tourism Growth Strategy [S.A.]: Gearing up to be globally competitive. Pretoria. Department of Environmental Affairs and Tourism.

SAT [South Africa Tourism] (2008). The Marketing Tourism Growth Strategy for South Africa: 2008-2010. Pretoria. Department of Environmental Affairs and Tourism.

Smith, M. (2003). Issues in cultural tourism studies. London. Routledge.

Timothy, D. J. \& Boyd, S. W. (2006). Heritage Tourism in the $21^{\text {st }}$ Century: Valued Traditions and New Perspectives. Journal of Heritage Tourism I (I) I - 16.

Van Vuuren, E. J. (2004). Cultural Village Tourism in South Africa. Capitalizing in Indigenous Culture. In C. Rogerson \& G. Visser (eds), Tourism and Development Issues in Contemporary South Africa. Pretoria: Africa Institute of South Africa.

Viljoen, J. \& Tlabela, K. (2007). Rural Tourism Development in South Africa. Pretoria: HSRC Press.

Viljoen, J., Ringdahl, B., Adams, W. \& Tlabela, K. (2004). Community participation in tourism ventures: A quest for sustainability. Pretoria: HSRC: Final Research Report (April).

Visser, G. (2004). South African Tourism and its role in the perpetuation of an uneven tourism space economy. Tourism and Development Issues in Contemporary South Africa, 268-289. Pretoria: African Institute of South Africa.

Wahab, S. \& Pigram, J. J. (eds) (2004). Tourism Development and Growth: The Challenges of Sustainability. New York: Routledge. 